\title{
Faktor Risiko Kejadian Presbiopia Dini
}

\author{
Nur Hajri Rabbani ${ }^{1}$, Desi Utami Helisarah ${ }^{2}$, Suparni ${ }^{3}$, Motris Pamungkas ${ }^{4}$ \\ ${ }^{1,2,4}$ Program Studi Diploma Tiga Refraksi Optisi, STIKes Dharma Husada Bandung \\ ${ }^{3}$ Program Studi Sarjana Kesehatan Masyarakat, STIKes Dharma Husada Bandung \\ nsuparni@stikesdhb.ac.id
}

\begin{abstract}
ABSTRAK
Faktor risiko paling signifikan untuk presbiopia adalah usia. Namun, ketika gejala presbiopia terjadi lebih awal dari biasanya, itu disebut dengan presbiopia dini. Presbiopi dini adalah berkurangnya kemampuan akomodasi penglihatan jarak dekat mata yang lebih cepat dari perkiraan. Penelitian ini merupakan upaya untuk mengetahui apa saja faktor risiko yang dapat menyebabkan terjadinya presbiopia dini. Melakukan kajian literatur untuk mengetahui distribusi usia kejadian presbiopia dini dan mengetahui faktor risiko yang berhubungan dengan presbiopia dini. Penelitian ini dilakukan dengan metode study literature yaitu cara yang dipakai untuk menghimpun data-data atau sumbersumber yang berhubungan dengan topik yang diangkat dalam suatu penelitian. Berdasarkan hasil kajian literatur dari beberapa jurnal dan hasil penelitian menunjukan bahwa kisaran usia penderita presbiopia dini berada pada jarak usia 36-39 tahun. Adapun faktor risiko yang mempengaruhi kejadian presbiopia dini yaitu : jenis kelamin (gender), penggunaan gadget dan aktivitas melihat dekat, kebiasaan merokok dan penggunaan tembakau, dan kelainan refraksi. Diharapkan kajian literatur ini dapat digunakan sebagai prediksi awal dalam penatalaksanaan pemeriksaan mata dasar dilihat dari aktivitas kesehariannya dan pola hidupnya dan juga diharapkan kajian literatur dapat ini menjadi acuan bagi refraksionis optisien dalam menangani pasien yang memiliki keluhan melihat dekat agar tidak ragu dalam memberikan koreksi addisi kepada pasien dengan usia <40 tahun. Diharapkan kajian literatur ini dapat digunakan sebagai prediksi awal dalam penatalaksanaan pemeriksaan mata dasar dilihat dari aktivitas kesehariannya dan pola hidupnya.
\end{abstract}

Kata Kunci : Presbiopia Dini, Faktor Risiko

\begin{abstract}
The most significant risk factor for presbyopia is age. However, when symptoms of presbyopia occur earlier than usual, it is called premature presbyopia. Premature presbyopia is a reduction in the ability to accommodate near-eye vision that is faster than expected. This research is an attempt to find out what are the risk factors that can causes premature presbyopia. To conduct a literature review to determine the age distribution of premature presbyopia and determine risk factors associated with premature presbyopia. This research was conducted by the method of literature review which is a method used to collect data or sources related to the topics raised in a study. Based on the results of literature review from several journals and research results show that the age range of patients with premature presbyopia is at the age range of 36-39 years. The risk factors that affect the incidence of premature presbyopia are: sex (gender), gadget users and near work, smoking and tobacco use, and refractive errors. It is hoped that this literature review can be used as an initial prediction in the management of basic eye examinations seen from their daily activities and lifestyle and it is also hoped that this literature review can be a reference for refractionist opticiant in dealing with patients who have near vision complaints so as not to hesitate in providing correction of additions to patients with age $<40$ years. It is hoped that this literature review can be used as an initial prediction in the management of basic eye examination seen from their daily activities and lifestyle.
\end{abstract}

Keywords $\quad$ : Premature Presbyopia, Fact and Risk 


\section{Pendahuluan}

Mata merupakan salah satu indera tubuh yang berfungsi untuk melihat. Mata dapat menyesuaikan diri dengan jarak dan cahaya ketika melihat objek. Fungsi mata dapat menurun seiring dengan bertambahnya usia. Namun gangguan terhadap penglihatan banyak terjadi, mulai dari gangguan ringan hingga gangguan yang berat yang dapat mengakibatkan kebutaan.

Masalah penglihatan yang penting bagi negara maju dan negara berkembang adalah low vision dan kebutaan. Data terbaru dari World Health Organization (WHO) memperkirakan penyebab terbesar perubahan kehidupan jutaan manusia adalah gangguan visual. Sekitar $80 \%$ dari semua penyebab ganggungan penglihatan dapat dicegah atau disembuhkan. (Kemenkes, 2014)

Kondisi kelainan refraksi mata yang perlu diketahui, beberapa diantaranya adalah miopia (rabun jauh), hipermetropia (rabun dekat), astigmatisme (silindris), dan presbiopia (rabun dekat usia lanjut). Miopia (rabun jauh) biasanya kesulitan melihat jauh dengan jelas, hipermetropia (rabun dekat) kesulitan melihat dekat dengan jelas, astigmatisme (silindris) yaitu terjadinya distorsi penglihatan akibat kelengkungan kornea dan lensa yang tidak sama di berbagai meridian, presbiopia (rabun dekat usia lanjut) suatu perubahan fisiologis yang terjadi pada usia $>40$ tahun dimana daya akomodasi berkurang. (Kemenkes P. , 2018)

Orang dewasa yang berusia lebih dari 40 tahun dapat mengalami gangguan saat melihat benda dengan jarak dekat. Selain itu mata juga dapat terjadi gangguan karena terdapat aktifitas yang diyakini dapat menyebabkan masalah pada penglihatan. Faktor risiko paling signifikan untuk presbiopia adalah usia. Namun, ketika gejala presbiopia terjadi lebih awal dari biasanya, itu disebut dengan presbiopia dini. Jika terjadi gejala presbiopia pada usia lebih awal dari onset normal, itu mungkin merupakan tanda dari kondisi medis yang mendasarinya. (Giorgi, 2016)

Data presbiopia dini yang dikeluarkan oleh Sujata Priyambada berdasarkan penelitiannya yang dilakukan di rumah sakit didapatkan hasil bahwa penelitiannya melibatkan total 4106 penderita presbiopia dimana $494(12,03 \%)$ penderita mengalami presbiopia dini. Diantaranya sebanyak 302 $(61,13 \%)$ penderita presbiopia dini adalah perempuan dan $192(38,87 \%)$ penderita presbiopia dini adalah laki-laki. Rata-rata usia penderita presbiopia dini adalah 36 tahun, dan usia terendah berada di 32 tahun. Koreksi yang diperlukan rata-rata berkisar $+1,19$ untuk lakilaki dan $+1,30$ untuk perempuan.

Kemampuan akomodasi yang berkurang pada penderita presbiopia dini menjadikan penderitanya tidak dapat membaca dekat dengan jelas di usia awal 30 tahun, yang dikarenakan oleh lingkungan (kebiasaan aktivitas melihat dekat dan pola hidup), penyakit yang berhubungan dengan presbiopia, atau obat obatan. Seseorang yang memiliki pekerjaan dekat memerlukan penglihatan dekat yang ekstensif, (Priyambada, 2019)

Pada penderita presbiopia dini, kemampuan fungsi akomodasi berkurang untuk melakukan aktivitas melihat dekat pada 
pasien yang memiliki usia sebelum 40 tahun, hal ini bisa terjadi karena faktor lingkungan, asupan gizi, penyakit sistemik, ataupun penggunaan obat-obatan. (Fasih, 2014)

Perubahan lingkungan pada tempat kerja, seperti teknologi komputer dapat mempengaruhi gangguan visual. Kondisi lain seperti diabetes mellitus, penyakit pembuluh darah, trauma, dan merokok juga dilaporkan terkait dengan presbiopia dini. (Priyambada, 2019)

Bekerja adalah kegiatan ekonomi yang dilakukan oleh seseorang dengan maksud memperoleh pendapatan atau keuntungan. Namun, bekerja dekat dalam waktu yang lama dapat berisiko terhadap kelelahan mata. Bekerja dekat seperti penjahit, tukang jam, pengguna mikroskop, dan lain-lain. Dalam pekerjaan apapun mata sangat berperan penting untuk membantu dan mendukung pekerjaan tersebut. Apalagi bila pekerjaan tersebut membutuhkan jarak yang dekat dengan mata, maka akan membutuhkan akomodasi yang lebih kuat. (Kesehatan, 2006)

\section{Metode Penelitian}

\section{a. Pencarian Literatur}

Pencarian literatur dilakukan pada database di perpustakaan elektronik, yaitu dengan penulusuran di internet melalui google scholar, Indonesia onesearch, PubMed, NCBI, aaojournal, JAMA, dan lainnya. Dalam pencarian literatur artikel ilmiah atau jurnal, perlu ditentukan kata kunci untuk memudahkan dalam pemilahan artikel. Kata

Pencarian literature dilakukan dengan menggunakan kata kunci yang dikembangkan dari metode PICO (Population/Problem; Intervention; Comparison; Outcome). Kata kunci yang digunakan dalam pencarian literatur artikel atau jurnal ilmiah berbahasa Indonesia adalah 'presbiopia', 'faktor risiko presbiopia', 'hubungan jenis kelamin dan presbiopia', 'umur dan presbiopia'. Adapun untuk pencarian artikel atau jurnal ilmiah berbahasa inggris, kata kunci yang digunakan adalah 'presbyopia', 'risk factors presbyopia', 'presbyopia and age, 'presbyopia and gender'.

Sumber data yang digunakan pada literatur review ini yaitu artikel atau jurnal ilmiah yang telah terakreditasi, kemudian dilakukan pemilahan literatur dengan menggunakan kriteria inklusi dan eksklusi. Kriteria inklusi adalah karakteristik umum dari suatu target yang akan dijadikan subjek penelitian. Kriteria inklusi yang digunakan dalam penelitian ini adalah:

1) Artikel menggunakan Bahasa Indonesia atau Bahasa Inggris.

2) Isi artikel mengacu pada lingkup penelitian yaitu tentang faktor risiko presbiopia dini.

3) Artikel merupakan jurnal penelitian yang telah terakreditasi. Untuk mengetahui jurnal yang terakreditasi, penulis menggunakan jurnal yang sudah ber ISSN, atau jurnal yang sudah terdaftar di SINTA, DIKTI atau LIPI untuk jurnal nasional, dan SCImago Journal Rank untuk jurnal internasional.

4) Rentang waktu penerbitan jurnal berbahasa Indonesia maksimal 5 tahun terakhir (20162020), dan jurnal berbahasa Inggris maksimal 10 tahun terakhir (2011-2020). 
Adapun kriteria eksklusi adalah mengeluarkan atau menghilangkan beberapa subjek yang memenuhi kriteria inklusi dari penelitian dikarenakan kriteria dan sebab-sebab tertentu. Kriteria eksklusi dalam penelitian ini adalah: artikel tidak dalam bentuk full teks (tidak dapat diakses penuh).

\section{b. Pengumpulan Literatur}

Berikut merupakan bagan alur pengumpulan literatur review dari beberapa database artikel atau jurnal ilmiah.

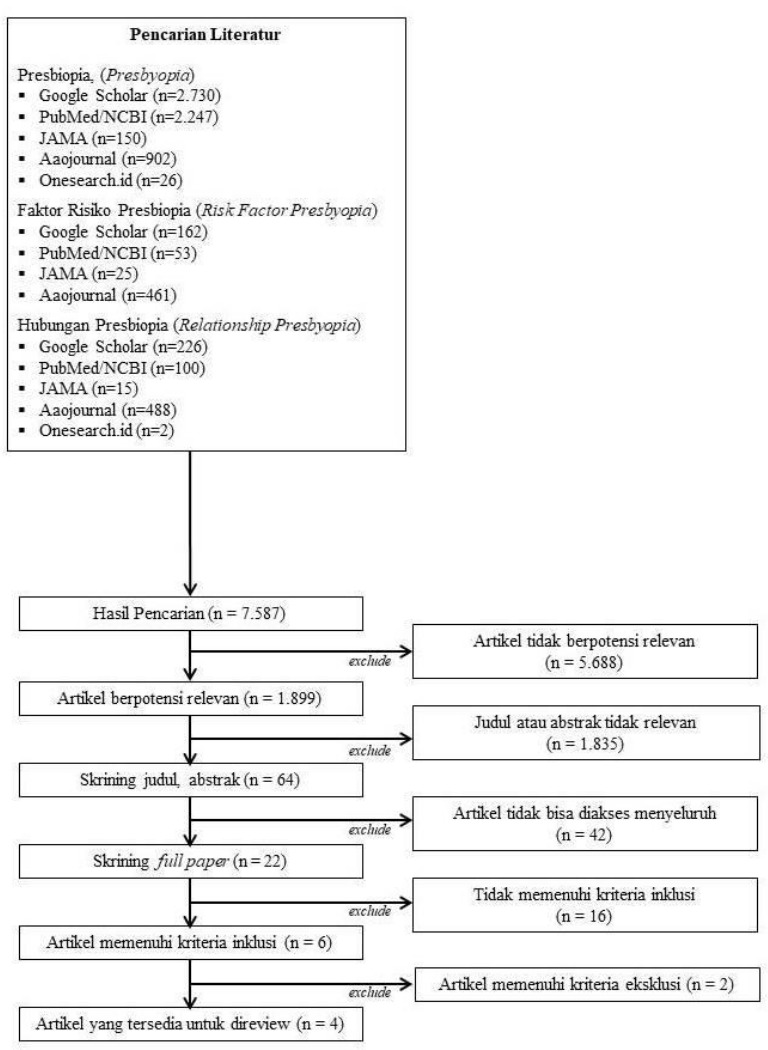

Bagan 1. Matriks Pengumpulan Literatur
Dalam penyaringan daftar referensi dari artikel ilmiah yang diproses atau yang dijadikan sebagai sumber rujukan, kemudian penulis membuat satu folder khusus sumber referensi. Dalam pengumpulan referensi sumber rujukan, penulis menggunakan aplikasi mendeley. Aplikasi mendeley ini sangat membantu dalam pengumpulan artikel atau citation, sehingga memudahkan penulis dalam memasukkan daftar referensi citation yang digunakan ketika penyusunan penelitian.

\section{c. Analisis dan Sintesis Literatur}

Metode tinjauan literatur yang penulis gunakan adalah metode naratif review, yaitu metode review yang menggambarkan dan menilai artikel yang diterbitkan dengan mensintesis informasi ke dalam format yang mudah digunakan, dimana pengumpulan fakta dan sintesisnya tidak mengikuti cara-cara yang baku yang tersusun secara sistematis.

Dalam kajian literatur ini, penulis memilih beberapa literatur yang dijadikan sebagai sumber referensi yang disesuaikan dengan kriteria inklusi penelitian. Setelah membaca dan memahami setiap ide pokok dari literatur yang dipilih, kemudian penulis membuat matriks literatur untuk membantu dalam menganalisis dan mensintesis literatur. 


\section{HASIL DAN PEMBAHASAN}

a. Hasil

Tabel 1 Matrik Jurnal

\begin{tabular}{|c|c|c|c|c|}
\hline $\begin{array}{c}\text { No. } \\
\text { Jurnal }\end{array}$ & $\begin{array}{l}\text { Nama, Judul, } \\
\text { Tahun Publikasi }\end{array}$ & Metode Penelitian & & Hasil Penelitian \\
\hline 1 & $\begin{array}{l}\text { Judul Jurnal : } \\
\text { "Premature } \\
\text { Presbyopia and its } \\
\text { Risk Factors - A } \\
\text { Hospital based } \\
\text { Study." }\end{array}$ & $\begin{array}{l}\text { Sumber Data : } \\
\text { Studi ini merupakan } \\
\text { studi prospektif berbasis } \\
\text { rumah sakit yang } \\
\text { dilakukan pada pasien } \\
\text { rawat jalan yang datang } \\
\text { ke departemen Hi-Tech } \\
\text { Medical College and } \\
\text { Hospital di distrik } \\
\text { Sundergarh, Odisha dari } \\
\text { bulan Oktober } 2016 \\
\text { sampai dengan bulan } \\
\text { Oktober } 2018 \text {. }\end{array}$ & $\begin{array}{l}\text { d. } \\
\\
\text { e. }\end{array}$ & 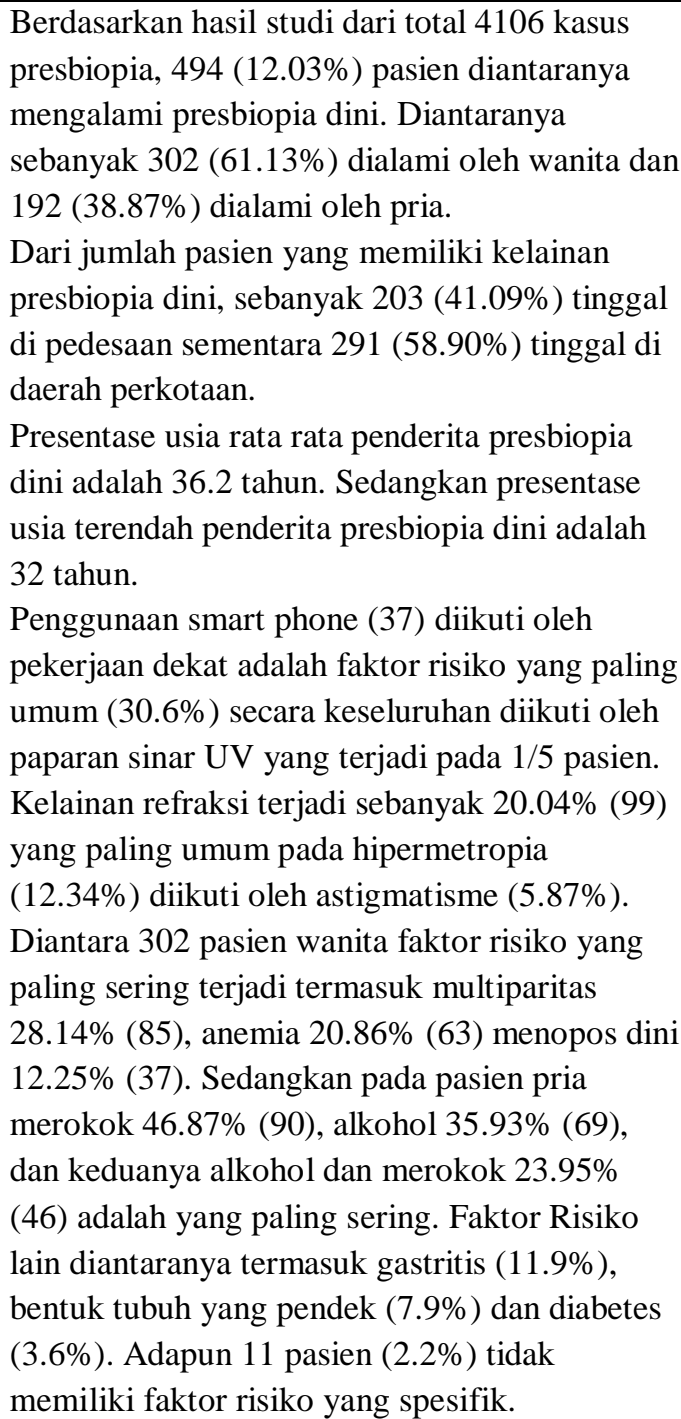 \\
\hline 2 & $\begin{array}{l}\text { Nama Peneliti : } \\
\text { Dr Manoj } \\
\text { Venugopal, Dr } \\
\text { Ann Tresa Antony } \\
\text { Judul Jurnal : } \\
\text { "A Study of } \\
\text { Clinical Profile of } \\
\text { Premature } \\
\text { Presbyopia in A } \\
\text { Tertiary Care } \\
\text { Hospital." }\end{array}$ & $\begin{array}{l}\text { Sumber Data : } \\
\text { Penelitian ini dilakukan } \\
\text { di departemen } \\
\text { opthalmologi rumah } \\
\text { sakit tertiary care selama } \\
\text { periode } 6 \text { bulan. } \\
\text { Sebanyak } 36 \text { pasien } \\
\text { dengan keluhan } \\
\text { penglihatan dekat yang } \\
\text { kurang baik dibawah usia } \\
40 \text { tahun menghadiri } \\
\text { departemen opthalmologi } \\
\text { secara rawat jalan } \\
\text { dilibatkan dalam }\end{array}$ & c. & $\begin{array}{l}\text { Penelitian ini menunjukan bahwa seorang } \\
\text { wanita lebih dominan karena disebabkan oleh } \\
\text { stress berat dan juga ditemukan pekerja } \\
\text { kantoran adalah kelompok yang terkena dampak } \\
\text { paling tinggi terkena presbiopia dini. } \\
\text { Dalam studi saat ini didapatkan } 60 \% \text { emetrop } \\
\text { untuk penglihatan jarak jauh, } 30 \% \text { mengalami } \\
\text { hipermetropia dan } 10 \% \text { mengalami miopia. } \\
\text { Telah ditemukan bahwa } 24 \% \text { pasien di rumah } \\
\text { sakit saat penelitian ini adalah pengkonsumsi } \\
\text { tembakau dan } 40 \% \text { adalah perorok. Menurut } \\
\text { studi ini } 35.1 \% \text { dari subjek penelitian yang } \\
\text { berusia } 35 \text { tahun memiliki kelainan presbiopia } \\
\text { dini dan mereka adalah pengguna tembakau. }\end{array}$ \\
\hline
\end{tabular}




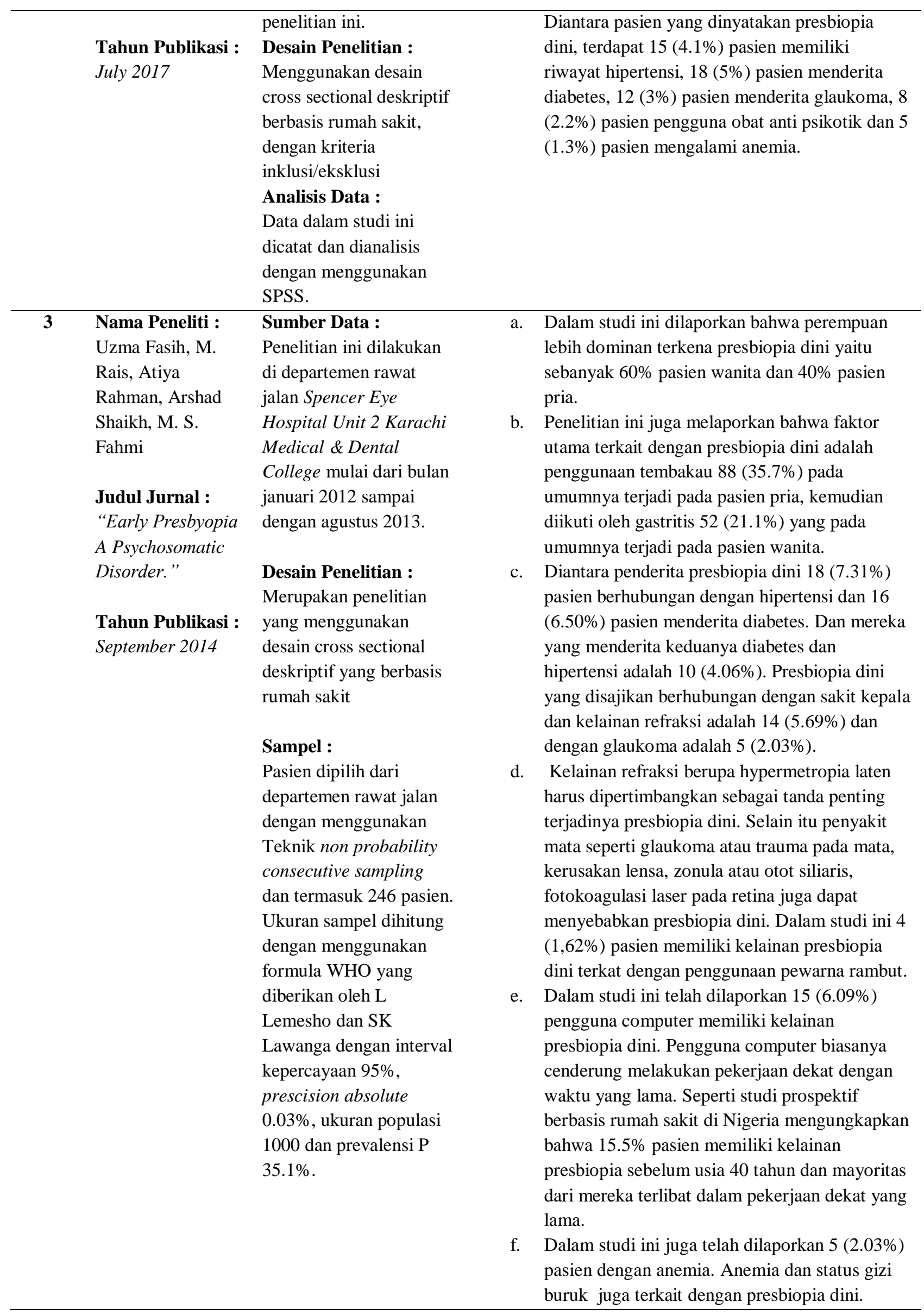




\begin{tabular}{|c|c|c|c|c|}
\hline & & $\begin{array}{l}\text { Analisis Data : } \\
\text { Data dicatat dan } \\
\text { dianalisis dengan } \\
\text { menggunakan program } \\
\text { SPSS versi } 14 .\end{array}$ & & $\begin{array}{l}\text { Faktor yang kurang lazim terkait dengan } \\
\text { presbiopia dini adalah perokok } 7(2.84 \%) \\
\text { pasien. Glaukoma } 5(2.03 \%) \text {, anemia } 5(2.03 \%) \text {, } \\
\text { penyakit tiroid } 4(1.6 \%) \text {, osteoarthritis } 2 \\
(0.81 \%) \text { dan gangguan alergi } 2(0.81 \%) \text {. } \\
\text { Sedangkan pasien yang dating tanpa sebab yang } \\
\text { spesifik adalah } 4(1.62 \%) \text {. }\end{array}$ \\
\hline 4 & $\begin{array}{l}\text { Nama Peneliti : } \\
\text { Deepak Mishra, } \\
\text { Prashant Bhushan, } \\
\text { M. K. Singh, } \\
\text { Bhavesh Makkar, } \\
\text { B. P Sinha, Gyan } \\
\text { Bhaskar } \\
\text { Judul Jurnal : } \\
\text { "Prospective } \\
\text { clinical study to } \\
\text { find out } \\
\text { epidemiology of } \\
\text { presbyopia in a } \\
\text { prepresbyopic } \\
\text { population (age } \\
\text { group 34-40 } \\
\text { years)." } \\
\text { Tahun Publikasi : } \\
\text { May-August } 2019\end{array}$ & $\begin{array}{l}\text { Sumber Data : } \\
\text { Penelitian ini sebuah } \\
\text { studi klinis prospektif } \\
\text { yang dilakukan pada } \\
2296 \text { pasien di dua pusat } \\
\text { perawatan tersier di } \\
\text { India. Lama studi yang } \\
\text { dilakukan adalah selama } \\
3 \text { tahun } 8 \text { bulan. } \\
\text { Desain Penelitian : } \\
\text { Merupakan studi klinis } \\
\text { prospektif multicenter } \\
\text { yang dilakukan pada dua } \\
\text { pusat perawatan tersier di } \\
\text { India. } \\
\text { Sampel : } \\
\text { Ukuran sampel dihitung } \\
\text { dengan menggunakan } \\
\text { Teknik dari WHO yang } \\
\text { diformulasikan oleh } \\
\text { Lwanga dan Lemeshow } \\
\text { dengan penetapan } \\
\text { interval kepercayaan } \\
\text { sebesar 95\%, dengan } \\
\text { surasi penelitian selama } \\
\text { 48 bulan. Selain itu, } \\
\text { dalam penelitian ini juga } \\
\text { ada kriteria inklusi dan } \\
\text { eksklusi. } \\
\text { Analisis Data : } \\
\text { Data dianalisis dengan } \\
\text { menggunakan program } \\
\text { SPSS versi 16 IBM. }\end{array}$ & $\begin{array}{l}\text { c. } \\
\text { d. }\end{array}$ & 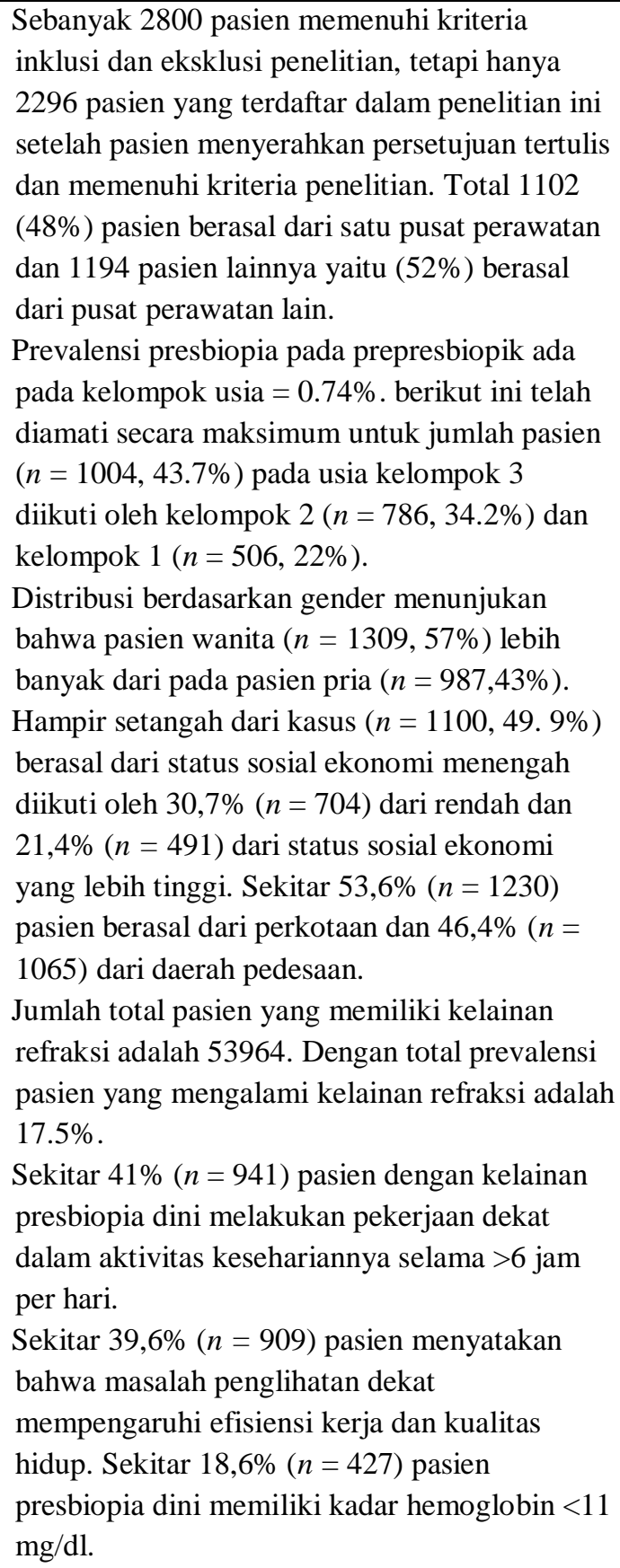 \\
\hline
\end{tabular}


JURNAL SEHAT MASADA VOLUME XV

\section{b. Pembahasan}

Berdasarkan penelitian pada jurnal 1, distribusi usia kejadian presbiopia dini didapatkan hasil $1 \%$ penderita presbiopia dini usia 31 tahun s/d usia 33 tahun, $47 \%$ penderita presbiopia dini usia 34 tahun s/d usia 36 tahun dan $52 \%$ penderita presbiopia dini usia 37 tahun s/d usia 39 tahun.

Pada penelitian jurnal 3, distribusi usia kejadian presbiopia dini didapatkan hasil $18.29 \%$ (45 orang) penderita presbiopia dini usia 31 tahun s/d usia 33 tahun, 51.21\% (126 orang) penderita presbiopia dini usia 34 tahun s/d 36 tahun, 30.48\% (75 orang) penderita presbiopia dini usia 37 tahun s/d usia 39 tahun.

Pada penelitian jurnal 4, ditribusi usia kejadian presbiopia dini tidak dijelaskan secara rinci seperti pada jurnal 1 dan 3 tetapi didapatkan hasil bahwa ditemukan $62 \%$ dengan range usia 30-40 tahun menderita presbiopia dini, selain itu dalam penelitian ini juga ditemukan $55 \%$ pasien berusia 30 tahun menderita presbiopia dini, Hasil penelitian pada jurnal ini diperkuat oleh penelitian Duarte et al di Brazil yang menemukan prevalensi presbiopa dini pada 3000 pasien yang berusia 30 tahun.

Sedangkan pada penelitian di jurnal 2 tidak dijelaskan mengenai hasil distribusi usia kejadian presbiopia dini karena di jurnal 2 hanya menyebutkan sampel distribusi usia nya saja.

Selain usia, dalam penelitian pada jurnal juga mengungkapkan kecenderungan jenis kelamin (gender) yang berisiko lebih besar terhadap kejadian presbiopia dini.

\section{1) Faktor Risiko Jenis Kelamin (Gender)}

Berdasarkan penelitian pada jurnal 1 didapatkan hasil studi dari total 4106 kasus presbiopia, 494 (12.03\%) pasien diantaranya mengalami presbiopia dini. Diantaranya sebanyak 302 (61.13\%) dialami oleh perempuan dan 192 (38.87\%) dialami oleh laki-laki.

Pada penelitian jurnal 2 juga menunjukan bahwa seorang perempuan lebih dominan karena disebabkan oleh stres berat. Seperti dijelaskan dalam penelitian lain yang menunjukan peningkatan prevalensi presbiopia dini dikalangan perempuan.

Pada penelitian jurnal 3 pun hasilnya memperkuat hasil penelitian dari jurnal 1 dan 2 yaitu dalam studi pada jurnal 3 dilaporkan bahwa perempuan lebih dominan terkena presbiopia dini yaitu sebanyak $60 \%$ pasien perempuan dan $40 \%$ pasien laki-laki. Dalam studi ini perempuan lebih dominan karena fakta bahwa perempuan mengalami lebih banyak tekanan dalam masyarakat dibandingkan dengan laki-laki, ini termasuk multiparitas seperti yang dilaporkan dalam penelitian ini, membesarkan anak, anemia dan tekanan dalam rumah tangga yang lainnya.

Pada penelitian di jurnal 4 hasil penelitiannya juga kembali memperkuat hasil penelitian di jurnal 1,2, dan 3. Hasil penelitian di jurnal 4 melaporkan bahwa pasien perempuan lebih dominan dari pada pasien laki-laki dimana pasien perempuan ada $57 \%$ dan pasien laki-laki 43\%. Dalam penelitian ini didapatkan hasil bahwa perempuan lebih berisiko terkena presbiopia dini karena 
perempuan dianggap menanggung tekanan lebih besar dalam masyarakat dibandingkan dengan laki-laki, ini termasuk multiparitas, kegiatan mengasuh anak, anemia dan tekanan dalam rumah tangga lainnya. Hasil penelitian ini juga diperkuat oleh penelitian Weale yang juga melaporkan dominasi perempuan sebagai yang berisiko terkena presbiopia dini.

Berdasarkan hasil penelitian di jurnal 1,2,3, dan 4 didapatkan hasil bahwa kejadian presbiopia dini banyak dialami oleh perempuan. Hal ini terbukti dari ke 4 jurnal yang menyebutkan bahwa kecenderungan perempuan terhadap kejadian presbiopia ini disebabkan karena adanya gangguan psikosomatis yang mempengaruhi kesehatan fisik mereka.

\section{2) Faktor Risiko Penggunaan Gadget dan Aktivitas Melihat Dekat}

Berdasarkan hasil penelitian pada jurnal 1 penggunaan smart phone (37) diikuti oleh pekerjaan dekat adalah faktor risiko yang paling umum (30.6\%). Lebih dari setengah penderita presbiopia dini di daerah perkotaan adalah pengguna smart phone. Pengguna smart phone ini dapat meningkatkan tuntutan kebutuhan visual untuk pekerjaan melihat dekat sehingga faktor ini dapat dikaitkan dengan terjadinya presbiopia dini. Sebuah studi di Nigeria juga menyebutkan bahwa peningkatan tuntutan visual sebagai kontribusi utama faktor timbulnya presbiopia dini sebelum usia 40 tahun.

Sedangkan penelitian pada jurnal 2 berbeda dengan jurnal 1 dimana smart phone tidak dimasukan ke dalam faktor risiko kejadian presbiopia dini tetapi aktivitas melihat dekat yang dimasukan ke dalam faktor risiko kejadian presbiopia dini dengan hasil penelitian ditemukan pekerja kantoran adalah kelompok yang terkena dampak paling tinggi terhadap kejadian presbiopia dini. Pekerja kantoran pada sektor pemerintah dan swasta memiliki jumlah intervensi presbiopia dini yang tergolong tinggi dibandingkan dengan yang lainnya. Penyebab dari hasil ini adalah karena pekerja kantoran cenderung memiliki tugas utama yang menuntut aktivitas visual seperti membaca, menulis dan berhubungan dengan komputer.

Pada penelitian di jurnal 3 juga berbeda dengan jurnal 1 dimana pada jurnal 3 ini tidak memasukan smart phone ke dalam faktor risiko kejadian presbiopia dini melainkan aktivitas melihat dekat dan penggunaan gadget berupa komputer kedalam faktor risiko kejadian presbiopia dini dengan hasil penelitian ditemukan bahwa $15 \quad(6.09 \%)$ pengguna komputer memiliki kelainan presbiopia dini. Pengguna komputer biasanya cenderung melakukan pekerjaan dekat dengan waktu yang lama. Seperti studi prospektif berbasis rumah sakit di Nigeria mengungkapkan bahwa $15.5 \%$ pasien memiliki kelainan presbiopia sebelum usia 40 tahun dan mayoritas dari mereka terlibat dalam pekerjaan dekat yang lama. Dengan demikian penggunaan penglihatan dalam bekerja dekat adalah faktor yang berkontribusi besar terhadap timbulnya kelainan presbiopia pada usia 35 tahun, meskipun usia adalah faktor risiko utama dari kelainan presbiopia. 
Pada penelitian jurnal 4 pun sama seperti pada jurnal 2 dan 3 dimana smart phone tidak dimasukkan ke dalam faktor risiko kejadian presbiopia dini melainkan hanya aktivitas melihat dekat saja yang dimasukkan ke dalam faktor risiko kejadian presbiopia dini dengan hasil penelitian bahwa pasien yang melakukan pekerjaan dekat dalam kesehariannya dengan durasi > 6 jam per hari dan bearsal dari daerah perkotaan lebih rentan terhadap kejadian presbiopia dini. Hasil penelitian ini diperkuat oleh hasil penelitian dari Kamali et al yang menemukan bahwa daerah tempat tinggal perkotaan yang memiliki aktivitas melihat dekat lebih sering secara signifikan berpengaruh terhadap prevalensi kejadian presbiopia dini.

Berdasarkan hasil penelitian pada jurnal 1,2,3, dan 4 ditemukan hasil yang sama yaitu faktor risiko penggunaan gadget dan aktivitas melihat dekat yang sangat mempengaruhi kejaidan presbiopa dini dengan range usia 3040 tahun, selain itu hal ini juga diperkuat oleh teori-teori mengenai disfungsi akomodasi yang terjadi pada pelaku aktivitas melihat dekat dan pengaruh sinar biru yang dipancarkan oleh layar gadget yang mempengaruhi fungsi internal bola mata.

\section{3) Faktor Risiko Kebiasaan Merokok dan Penggunaan Tembakau}

Berdasarkan hasil penelitian pada jurnal 1, fokus hasil penelitian pada faktor risiko ini cenderung lebih ditujukan untuk laki-laki dengan hasil pada pasien laki-laki merokok $46.87 \%$ (90) adalah yang paling sering dilaporkan terkait dengan kejaidan presbiopia Jurnal Penelitian Kesehatan STIKes Dharma Husada Bandung dini pada laki-laki. Sejumlah (47\%) pasien laki-laki adalah perokok. Hasil ini diperkuat oleh penelitian Hafez dkk di Iran dengan menunjukan timbulnya kelainan presbiopia dini pada laki-laki disebabkan oleh kebiasaan merokok dan penelitian Fasih dkk menunjukan $35 \%$ penderita presbiopia dini adalah pengunyah tembakau.

Pada penelitian di jurnal 2, telah ditemukan bahwa $24 \%$ pasien di rumah sakit saat penelitian ini adalah pengkonsumsi tembakau dan $40 \%$ adalah perorok. Menurut studi ini $35.1 \%$ dari subjek penelitian yang berusia 35 tahun memiliki kelainan presbiopia dini dan mereka adalah pengguna tembakau. Kondisi kehidupan yang pebuh dengan tekanan menyebabkan peningkatan pengguna tembakau sehingga memicu timbulnya kelainan presbiopia dini.

Sedangkan pada penelitian jurnal 3, sedikit berbeda dengan penelitian pada jurnal 1 dan 2 yang dimana status perokok disini dipisahkan bahasannya dengan penggunaan tembakau. Pada penelitian di jurnal 3 ini perokok masuk ke dalam faktor yang kurang lazim terkait dengan presbiopia dini adalah perokok 7 (2.84\%) pasien. Sedangkan dalam penelitian ini juga melaporkan bahwa faktor utama terkait dengan presbiopia dini adalah penggunaan tembakau 88 (35.7\%) pada umumnya terjadi pada pasien laki-laki. Pengguna tembakau biasanya terkait dengan kondisi kehidupan yang penuh tekanan dengan begitu presbiopia dini bisa menjadi gangguan psikosomatis. 
Sedangkan pada jurnal 4 berbeda dengan jurnal 1,2, dan 3 karena pada jurnal 4 sama sekali tidak membahas kebiasaan merokok dan penggunaan tembakau sebagai salah satu faktor risiko kejadian presbiopia dini.

Berdasarkan hasil penelitian pada jurnal 1,2, dan 3 yang membahas mengenai kebiasaan merokok dan penggunaan tembakau sebagai salah satu faktor risiko kejadian presbiopia dini telah dibuktikan dengan teori-teori diatas mengenai kandungan zat senyawa kimia yang ada pada rokok/tembakau yang dalam penggunaannya dapat merusak jaringan persyarafan pada bagian internal bola mata dan mempercepat pertumbuhann nukleus pada lensa mata sehingga merusak ke elastisitasan lensa serta membuat lensa mengalami sklerosis.

\section{4) Faktor Risiko Kelainan Refraksi}

Berdasarkan penelitian pada jurnal 1, didapatkan hasil kelainan refraksi terjadi sebanyak $20.04 \%$ (99) yang paling umum pada hipermetropia (12.34\%) diikuti oleh astigmatisma (5.87\%).

Pada penelitian di jurnal 2, dalam studi saat ini didapatkan $60 \%$ emetrop untuk penglihatan jarak jauh, 30\% mengalami hipermetropia dan 10\% mengalami miopia. Hasil penelitian pada jurnal 2 ini diperkuat oleh penelitian lain yang dilakukan oleh Keziah N. Malu, dkk dalam penelitian mereka menemukan (51.65\%) pasien emetropia, $(32.57 \%)$ pasien memiliki kelainan hipermetropia dan (15.76\%) pasien memiliki kelainan miopia. Hal ini menunjukan bahwa kelainan hipermetropia memiliki risiko lebih besar terkena presbiopia dibandingkan dengan kelainan miopia dari kelompok usia yang sama.

Pada penelitian di jurnal 3, presbiopia dini yang disajikan berhubungan dengan sakit kepala dan kelainan refraksi adalah 14 (5.69\%). Kelainan refraksi berupa hipermetropia laten harus dipertimbangkan sebagai tanda penting terjadinya presbiopia dini. Selain itu penyakit mata seperti glaukoma atau trauma pada mata, kerusakan lensa, zonula atau otot siliaris, fotokoagulasi laser pada retina juga dapat menyebabkan presbiopia dini.

Sedangkan pada penelitian jurnal 4, didapatkan hasil total prevalensi pasien yang mengalami kelainan refraksi adalah $17.5 \%$. Hasil penelitian pada jurnal 4 ini berbeda dengan penelitian pada jurnal 1,2 dan 3 dimana pada jurnal 1,2 dan 3 hasil penelitian nya saling menguatkan bahwa kelainan refraksi terutama kelainan hipermetropia menjadi faktor risiko yang cukup kuat untuk kejadian presbiopia dini. Pada jurnal 4 ini hanya di jelaskan secara umum saja mengenai besaran dari jumlah kelainan refraksi nya saja dan tidak dijelaskan lagi secara spesifik.

Berdasarkan pada hasil penelitian 1,2,3, dan 4 didapatkan kelainan refraksi terutama pada kelainan hipermetropia (rabun dekat) merupakan faktor risiko yang cukup kuat pada kejadian presbiopia dini hasil penelitian ini telah diperkuat oleh hasil penelitian lain juga yang menyatakan hipermetropia sebagai salah satu faktor risiko terjadinya presbiopia dini. Selain itu telah diperkuat oleh teori-teori yang 
menyatakan bahwa penderita hipermetropia pada usia lanjut akan mengalamai gangguan akomodasi yang dikarenakan oleh aktivitas visual yang terus memaksakan kinerja otot akomodasi, dan hal ini sejalan dengan kejadian presbiopia dini dimana mereka para penderitanya kehilangan keelastisitasan lensa matanya yang menyebabkann berkurangnya daya akomodasi pada mata mereka.

\section{KESIMPULAN}

Berdasarkan kajian literatur diatas, faktor risiko penyebab presbiopia dini bisa disebabkan oleh multifaktor. Baik instrinsik seperti jenis kelamin (gender), ataupun ekstrinsik seperti penggunaan gadget dan aktivitas melihat dekat, kebiasaan merokok dan penggunaan tembakau, kelainan refraksi, dan sebagainya

\section{DAFTAR PUSTAKA}

American Academy of Opthalmology Staff. (2014-2015a). Lens and Cataract. In Lang, Lens and Cataract. United State of America.

Dattalo, P. (2008). Determining Sample Size : Balancing Power, Precision, and Practicality. 198 Madison Avenue, New York: Oxford Univesity Press, Inc.

DHB StikesDHB. Buku Panduan Penyusunan Literature Review. 2020;21(1):1-9.

Dr. Eko Budiarto, S. (2004). Metodologi Penelitian Kedokteran : Sebuah Pengantar. Jakarta: Penerbit Buku Kedokteran EGC.

Dr. Mamik. S.KM., M. (2014). Metode Penelitian Kesehatan. Jakarta: Zifatama.
Fasih, U. (2014). Early Presbyopia A Psychosomatic Disorder. Pakistan Journal of Ophthalmology, 161-165.

Fathnur Sani K., M. A. (2018). Metodologi Penelitian Farmasi Komunitas dan Eksperimental. Yogyakarta: Deepublish.

G, S. (2005). Manajemen Keselamatan dan Kesehatan Kerja. Jakarta: Prestasi Pustaka.

Ganong, W. F. (2003). Buku Ajar Fisiologi Kedokteran Edisi 20. Jakarta: Jakarta : EGC.

Gary L. Mancil, O. (2010). OPTOMETRIC CLINICAL PRACTICE GUIDELINE. USA: American Optometric Association.

Gary L. Mancil, O. (2010). OPTOMETRIC CLINICAL PRACTICE GUIDELINE CARE OF THE PATIENT WITH PRESBYOPIA . United State American: American Optometric Association.

Giorgi, A. (2016). Presbyopia : Causes, Risk Factors, and Symptoms.

Hidayat, A. A. (2010). Metode Penelitian Kesehatan : Paradigma Kuantitatif. Jakarta: Health Books.

Kemenkes. (2014). Situasi Gangguan Penglihatan dan Kebutaan. Jakarta.

Kemenkes, P. (2018). Jenis-Jenis Kelainan Refraksi. Jakarta: p2ptm.kemkes.go.id.

Kesehatan, D. B. (2006). Pedoman Manajemen Kesehatan Dan Keselamatan Kerja (K3) Di Rumah Sakit. Jakarta: Jakarta Departemen Kesehatan.

Khurana, A. K. (2005). Opthalmology. New Delhi: New Age International (P) Limited.

Kim E. Barrett, d. (2002). Ganong's Review of Medical Physiology. United State of America: Lange. 
Notoatmodjo, P. D. (2012). Metodologi Penelitian Kesehatan. Jakarta: Rineka Cipta.

Nursalam. Konsep dan Penerapan Metodologi Penelitian Ilmu Keperawatan Pedoman Skripsi, Tesis dan Instrumen Penelitian Keperawatan. Jakarta: Salemba Medika; 2003.

Priyambada, S. (2019). Premature Presbyopia and its Risk Factors - A Hospital Based Study. Opthalmology.

Prof. dr. H. Sidarta Ilyas, S. (2010). Ilmu Penyakit Mata. Jakarta: Fakultas Kedokteran Universitas Indonesia.

Prof. Dr. Soekidjo Notoatmodjo, S. M. (2018). Metodologi Penelitian Kesehatan. Jakarta: Bineka Cipta.

Putra, I. P. (2014). PENURUNAN KADAR SUPEROKSIDA DISMUTASE LENSA BERHUBUNGAN DENGAN PENINGKATAN DERAJAT KEKERUHAN LENSA PADA KATARAK SENILIS. Program Pendidikan Dokter Spesialis Universitas Udayana, 1-5.

R, S. R. (2007). Parson's Diseases of The Eye. Indian : Elvesier.

S, A. (2010). Prosedur Penelitian Suatu Pendekatan Praktik. Jakarta: Rineka Cipta.

Sugiyono, P. D. (2017). Metode Penelitian : Kuantitatif, Kualitatif, dan R\&D. Jakarta: Alfabeta.

Suma'mur, D. (1967). Higinie Perusahaan dan Kesehatan Kerja. Jakarta: PT. Gunung Agung.

Tandan, S. d. (2007). Parson's Diseases of The Eye. Indiana : Elvesier.

Victor Trismanjaya Hulu, S. M. (2019). Analisis Data Statistik Parametrik Aplikasi SPSS dan STATCAL (Sebuah Pengantar Untuk Kesehatan). Jakarta: Yayasan Kita Menulis.

Jurnal Penelitian Kesehatan STIKes Dharma Husada Bandung
Wati, R. (2018). Akomodasi dalam Refraksi. jurnal.fk.unand.ac.id, 14 